\title{
Selenopentathionic and Telluropentathionic Acids as Precursors for Formation of Semiconducting Layers on the Surface of Polyamide
}

\author{
Skirma Zalenkiene, Judita Sukyte, Remigijus Ivanauskas, and Vitalijus Janickis \\ Department of Inorganic Chemistry, Kaunas University of Technology, Radvilenu pl. 19, 50254 Kaunas, Lithuania
}

Received 20 April 2006; Revised 8 August 2006; Accepted 8 August 2006

Recommended for Publication by Sabry Abdel-Mottaleb

The layers of copper chalcogenides, which were formed on the surface of semihydrophilic polymer-polyamide 6 (PA) using monoselenopentathionic $\mathrm{H}_{2} \mathrm{SeS}_{4} \mathrm{O}_{6}$ and monotelluropentathionic $\mathrm{H}_{2} \mathrm{TeS}_{4} \mathrm{O}_{6}$ acids as precursors of chalcogens, were characterized. Fourier transform infrared (FT-IR) and UV spectroscopy were used to monitor the effect of chalcogens on the changes in structure of PA corresponding to the concentration of the precursor's solution and an exposure time. The IR spectra of modified PA were completely different from that of the initial PA. Further interaction of chalcogenized PA with copper (II/I) salt solution leads to the formation of $\mathrm{Cu}_{x} \mathrm{~S}, \mathrm{Cu}_{x} \mathrm{Se}, \mathrm{Cu}_{x} \mathrm{Te}$, and mixed $-\mathrm{Cu}_{x} \mathrm{~S}-\mathrm{Cu}_{y} \mathrm{Se}$ and $\mathrm{Cu}_{x} \mathrm{~S}-\mathrm{Cu}_{y} \mathrm{Te}$ layers which have different electric transport properties. The surface properties of PA after treatment are studied using AFM and XRD. The electrical resistances of layers with various composition formed over a wide concentration range $0.01-0.5 \mathrm{~mol} \cdot \mathrm{dm}^{-3}$ of precursor's solution were measured. Variation in the conductivity of layers of $\mathrm{Cu}-\mathrm{Se}-\mathrm{S}$ and $\mathrm{Cu}-\mathrm{Te}-\mathrm{S}$ on the surface of PA shows an evident increase with the increasing of the mass fraction of selenium or tellurium.

Copyright (c) 2007 Skirma Zalenkiene et al. This is an open access article distributed under the Creative Commons Attribution License, which permits unrestricted use, distribution, and reproduction in any medium, provided the original work is properly cited.

\section{INTRODUCTION}

The semiconductors based on I-VI or II-VI groups' element compounds are important optoelectronic, luminescent, and lasing materials. Through the successful synthesis of I-VI compound semiconductors, a vide range of mechanical and optoelectronic applications may be possible for these materials, which is why the continued study of such semiconductors is of the greatest importance [1]. Copper chalcogenide thin films have a number of applications in various devices such as solar cells, super ionic conductors, photo-detectors, photothermal conversion, electroconductive electrodes, microwave shielding coating, and so forth [2-5]. Copper sulfide, selenide, and telluride belong to such copper chalcogenide (groups IVI compounds) materials. In the drive towards low-cost thin films solar cells, starting materials are used that are usual in the semiconductor industry. It was also found that the chemical and morphological properties or surfaces were correlated to the solar cell efficiency [6]. The formation of copper chalcogenides on the surface of semi- hydrophilic polymer-polyamide 6 (PA) using monoselenopentathionic $\mathrm{H}_{2} \mathrm{SeS}_{4} \mathrm{O}_{6}$ and monotelluropentathionic $\mathrm{H}_{2} \mathrm{TeS}_{4} \mathrm{O}_{6}$ acids as precursors of chalcogens-was discussed in this study.

\section{EXPERIMENTAL DETAILS}

The layers of copper chalcogenides were deposited on a PA (PK-4 specification TY 6-05-1775-76) tape of $70 \mu \mathrm{m}$ thickness. This polymer is close to a nonporous material, because the pores of PA are much less than $1.5 \mathrm{~nm}$. The porosity was measured by a $\beta$ method using a Quantasorb (Japan). Prior to the experiments, pieces of PA of $15 \times 70 \mathrm{~mm}$ in the size were boiled in distilled water for two hours to remove the remainder of the monomer. After that, they have been dried by filter paper and then in the dessicator over $\mathrm{CaCl}_{2}$ for 24 hours.

Monoselenopentathionic $\mathrm{H}_{2} \mathrm{SeS}_{4} \mathrm{O}_{6}$ and monotelluropentathionic $\mathrm{H}_{2} \mathrm{TeS}_{4} \mathrm{O}_{6}$ acids were isolated from their barium salts, $\mathrm{BaSeS}_{4} \mathrm{O}_{6} \cdot 2 \mathrm{H}_{2} \mathrm{O}$ and $\mathrm{BaTeS}_{4} \mathrm{O}_{6} \cdot 3 \mathrm{H}_{2} \mathrm{O}$, in the reaction of precipitation of $\mathrm{BaSO}_{4}$ with the solution of 
$\mathrm{H}_{2} \mathrm{SO}_{4}$ [7-9]. PA samples were treated 1 to 120 hours in 0.01 , $0.05,0.1$, and $0.5 \mathrm{~mol} \cdot \mathrm{dm}^{-3}$ aqueous solutions of isolated selenopentathionic and telluropentathionic acids at $20^{\circ} \mathrm{C}$.

For the formation of mixed $\mathrm{Cu}_{\mathrm{x}} \mathrm{S}_{\mathrm{y}}-\mathrm{Cu}_{\mathrm{x}} \mathrm{Te}_{\mathrm{y}}$ thin films, the samples of chalcogenized PA were treated with $\mathrm{Cu}(\mathrm{II} / \mathrm{I})$ salt solution at $78^{\circ} \mathrm{C}$. $\mathrm{Cu}(\mathrm{II} / \mathrm{I})$ salt solution was made from crystalline $\mathrm{CuSO}_{4} \cdot 5 \mathrm{H}_{2} \mathrm{O}$ and a reducing agent hydroquinone [10]. The details of the experimental set-up have already been described in two different publications [10-12].

UV spectra were recorded on a Spectronic ${ }^{R}$ Genesys $^{T M}$ $8 \mathrm{UV} / \mathrm{Visible}$ spectrophotometer with compensation of the absorption of PA in the range of $190-800 \mathrm{~nm}$. Fourier transform infrared (FT-IR) absorption spectra were obtained with a Perkin Elmer FT-IR Spectrum GX spectrometer in the range of $400-1400 \mathrm{~cm}^{-1}$.

Sheet resistance measurements at a constant current of $\mathrm{Cu}-\mathrm{Te}-\mathrm{S}$ and $\mathrm{Cu}-\mathrm{Se}-\mathrm{S}$ thin layers were done by a 4 -point probe technique. A geometric correction factor (CF) for the sample size, shape, and probe spacing was used to convert the voltage/current ratio measured by the 4-point probe into sheet resistance.

$\mathrm{X}$-ray diffraction measurements were made using a DRON 6 difractometer provided with a special device for beam limitation at low and medium diffraction angles equipped with graphite-monochromatized $\mathrm{Cu}-\mathrm{K} \alpha$ $(1.54178 \AA)$ source under a voltage of $30 \mathrm{kV}$ and a current of $30 \mathrm{~mA}$. The XRD patterns were recorded with a step size of $0.05^{\circ}$ from $2 \theta=30^{\circ}$ to $70^{\circ}$. Using the programs Search Match, Xfit, ConvX, Dplot 95, and Photo Styler to eliminate the maxima of PA, all the crystallographic calculations were performed.

Morphology of the surface of modified PA and quantitative microscopic studies of roughness of obtained layers on the surface of PA were performed by the atomic force microscope QUESANT QScope-250 (Quesant Corp., USA), in contact regime with ultra-resolution probes with force constant $k=0.2 \mathrm{~N} / \mathrm{m}$ (Micromash Corp.). The data of measurements were analyzed by means of computer programs: Scan Atomic $^{\mathrm{TM}}$, SPIP (Scaning Probe Image Processor). Areas of $10 \times 10$ microns were investigated; standard microscope programme equipment of image maintenance as well as specialized SPIP package (Image Metrology Corp.) was applied for quantitative evaluation of the surface [13].

\section{RESULTS AND DISCUSSION}

\subsection{Kinetics of sorption of chalcogens}

A mixed chain of three divalent chalcogen atoms ${ }^{-} \mathrm{O}_{3} \mathrm{~S}-\mathrm{S}-\mathrm{Te}-\mathrm{S}-\mathrm{SO}_{3}{ }^{-}$or ${ }^{-} \mathrm{O}_{3} \mathrm{~S}-\mathrm{S}-\mathrm{Se}-\mathrm{S}-\mathrm{SO}_{3}{ }^{-}$of low oxidation state is present in the anion of chalcopolythionates compounds [7, 14]. The formation of the layers of chalcogens from chalcopolythionic acids, namely, monoselenopentathionic $\mathrm{H}_{2} \mathrm{TeS}_{4} \mathrm{O}_{6}$ and telluropentathionic $\mathrm{H}_{2} \mathrm{TeS}_{4} \mathrm{O}_{6}$, has recently attracted interest. These precursors offer many advantages over the more conventional sources because of its higher stability [8,9]. It was established that under conditions of our experiment, solutions of selenopentathionic and telluropentathionic acids were

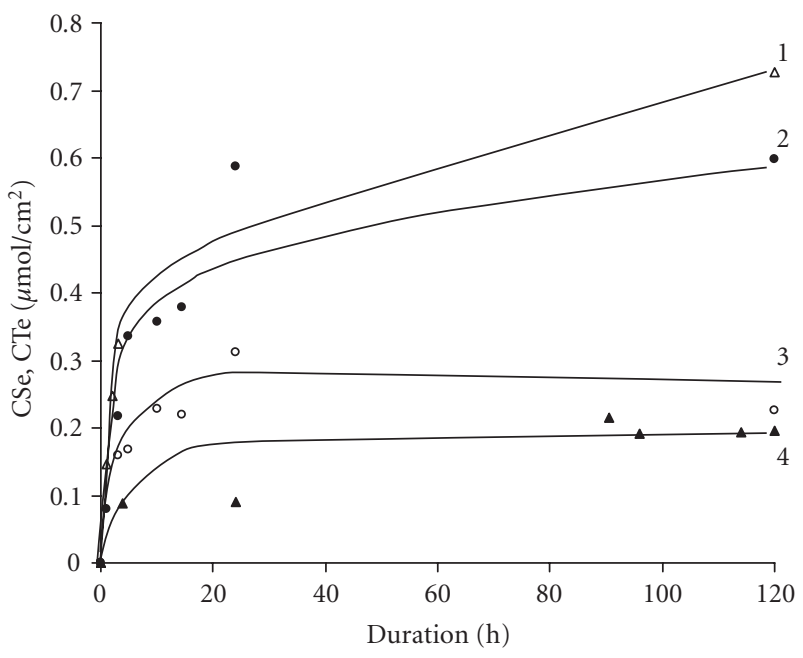

FIgURE 1: Kinetics of chalcogens' sorption on the surface of PA at $20^{\circ} \mathrm{C}$. Precursors are $-0.1 \mathrm{~mol} \cdot \mathrm{dm}^{-3} \mathrm{H}_{2} \mathrm{TeS}_{4} \mathrm{O}_{6}(1), 0.05 \mathrm{~mol} \cdot \mathrm{dm}^{-3}$ (2), $0.01 \mathrm{~mol} \cdot \mathrm{dm}^{-3}(3) \mathrm{H}_{2} \mathrm{TeS}_{4} \mathrm{O}_{6}$, and $0.5 \mathrm{~mol} \cdot \mathrm{dm}^{-3} \mathrm{H}_{2} \mathrm{SeS}_{4} \mathrm{O}_{6}$ (4).

more stable than their alkaline metal salt solutions of the same concentration [7, 14] which have been used in our previous experiments. The amount of sorbed tellurium and sulfur increases with the increase of the concentration of precursor's solution and an exposure time (Figure 1).

\subsection{UV-visible and FT-IR spectroscopy}

Typical UV spectra are presented in Figure 2, where the spectrum of PA substrate is excluded. Figure 2(a) shows spectrum of PA alone (absorption maximum at $210 \mathrm{~nm}$ ) as well as the spectra of PA chalcogenized in $0.5 \mathrm{~mol} \cdot \mathrm{dm}^{-3}$ selenopentathionic acid $\mathrm{H}_{2} \mathrm{SeS}_{4} \mathrm{O}_{6}$ and the spectrum of PA after treatment in $\mathrm{Cu}^{+} / \mathrm{Cu}^{2+}$ salt solution compared with the spectrum of PA. Figure 2(b) shows, respectively, the analogous spectra of PA chalcogenized in $0.1 \mathrm{MH}_{2} \mathrm{TeS}_{4} \mathrm{O}_{6}$ and the spectrum of PA treated in $\mathrm{Cu}^{+} / \mathrm{Cu}^{2+}$ salt solution.

Optical absorption spectra of the layers of chalcogens on PA showed the layers to have high absorbance $\left(10^{4} \mathrm{~cm}^{-1}\right)$ indicating direct band gap transition. In addition, the UV absorption spectra of chalcogens layers formed using selenopentathionic or telluropentathionic acids were very closely identical.

The absorption spectra maximum of selenium containing layers was at $\lambda=250-255 \mathrm{~nm}$ and, respectively, at $\lambda=$ 240-250 $\mathrm{nm}$ of that of tellurium. However, percentage transmission $(90 \%)$ of both, selenium and tellurium layers on PA, was maximum at $\lambda=780 \mathrm{~nm}$. The intensity of absorption spectra maximum with similar concentration of precursor's solution increased with the increasing of the exposure time (Figures 2(a), 2(b)). The increase in absorbance at maximum wavelength is also a precursor's concentration effect. The thickness of chalcogens' layers and the mol fraction of chalcogen grow with an exposure in the solution of 


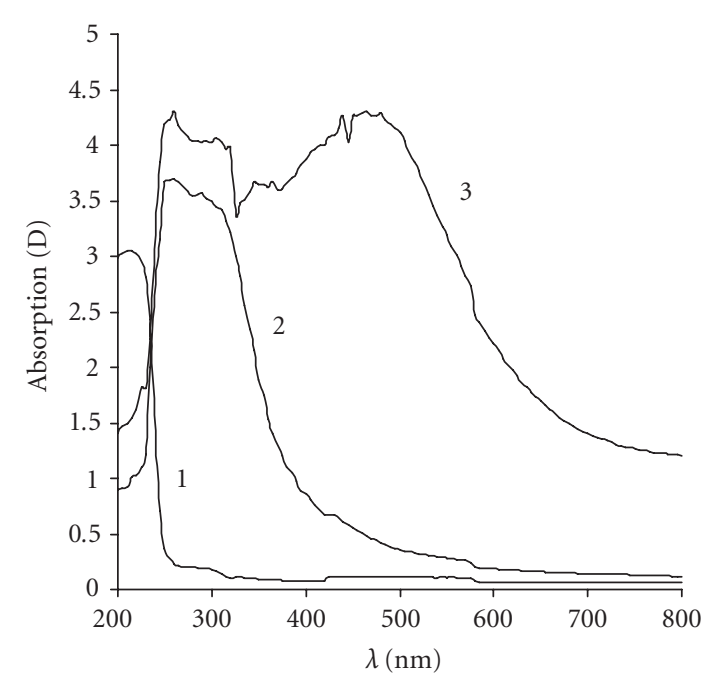

(a)

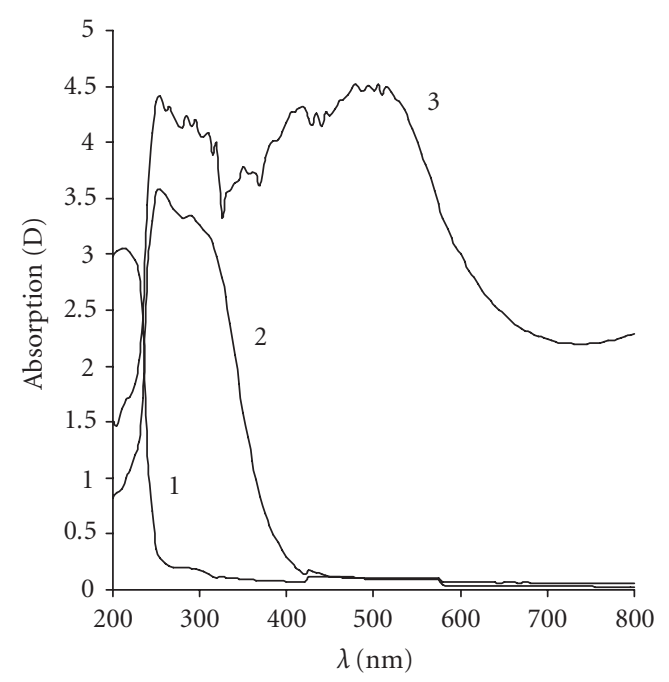

(b)

FIgURE 2: (a) Individual UV-VIS absorption spectra of PA (1), the layers of chalcogens on PA surface after 24 hours of exposure in $0.5 \mathrm{~mol} \cdot \mathrm{dm}^{-3}$ solution of $\mathrm{H}_{2} \mathrm{SeS}_{4} \mathrm{O}_{6}$ at $20^{\circ} \mathrm{C}$ (2), and copper chalcogenides on PA (3). (b) Individual UV-VIS absorption spectra of PA (1), the layers of chalcogens on PA surface after 24 hours of exposure in $0.1 \mathrm{~mol} \cdot \mathrm{dm}^{-3}$ solution of $\mathrm{H}_{2} \mathrm{TeS}_{4} \mathrm{O}_{6}$ at $20^{\circ} \mathrm{C}(2)$, and copper chalcogenides on PA after interaction with $\mathrm{Cu}^{+} / \mathrm{Cu}^{2+}(3)$.

precursor, however, thickness grows at the expense of transparency.

UV-VIS spectra showed also the presence of an additional, unclear peak at $290 \mathrm{~nm}$ for PA chalcogenized in both acids with an increase in the concentration of precursor's solution and the exposure time, for example, with an increase in the concentration of chalcogen on the surface of PA. The change of the shape in the spectra of chalcogenized PA before interaction with copper ions might be explained by appearance of tetrathionic acid $\mathrm{H}_{2} \mathrm{~S}_{4} \mathrm{O}_{6}$, the product of slight degradation (2-8\% from initial concentration) of both selenopentathionic and telluropentathionic acids after 24 hours and longer treatment of PA according the reaction:

$$
\begin{aligned}
& \mathrm{SeS}_{4} \mathrm{O}_{6}^{2-} \longrightarrow \mathrm{Se}+\mathrm{S}_{4} \mathrm{O}_{6}^{2-}, \\
& \mathrm{TeS}_{4} \mathrm{O}_{6}^{2-} \longrightarrow \mathrm{Te}+\mathrm{S}_{4} \mathrm{O}_{6}^{2-} .
\end{aligned}
$$

After interaction of copper ions with polyamide in the presence of chalcogens, a number of new peaks appear in the interval of $255-505 \mathrm{~nm}$ for PA chalcogenized in the selenopentathionic acid solution and 260-465 nm for PA chalcogenized in the telluropentathionic acid solution and a change tendency was observed in comparison with that before the interaction with copper.

Four obvious absorption peaks at $255 \mathrm{~nm}, 350 \mathrm{~nm}$, $420 \mathrm{~nm}$, and $505 \mathrm{~nm}$ appeared on the surface of PA chalcogenized in the solution of selenopentathionic acid (Figure 2(a), curve 3). When telluropentathionic acid was used as a precursor, a broad absorption peak and an unclear one appeared at $465 \mathrm{~nm}$ and $260 \mathrm{~nm}$, respectively (Figure 2(b), curve 3). All these peaks are higher than relevant peaks of PA before the interaction with copper indicating they are copper chalcogenides species. These data in Figure 2 are consistent with the number and intensity of copper chalcogenides phases detected according our XRD measurements. To describe copper chalcogenides formation in general terms, we use the formula $\mathrm{Cu}_{\mathrm{x}} \mathrm{Se}_{\mathrm{y}}, \mathrm{Cu}_{\mathrm{x}} \mathrm{Te}_{\mathrm{y}}$, or $\mathrm{Cu}_{\mathrm{x}} \mathrm{S}-\mathrm{Cu}_{\mathrm{y}} \mathrm{Se}$ and $\mathrm{Cu}_{\mathrm{x}} \mathrm{S}-\mathrm{Cu}_{\mathrm{y}} \mathrm{Te}$ $[10,11]$. It suggested that these new peaks show copper selenides-tellurides or mixed copper sulfides-selenides or copper tellurides-sulfides are produced after interaction with copper ions. In order to clarify the structural attribution of the new UV-VIS absorption bands, some experiments have to be carried out. Several of methods used yield information but the interpretation of the data on the surface of PA is complicated. Our future experiments will be focused on the mechanism in the water solutions and further interpreted to the reactions on $\mathrm{PA}$.

The IR spectra of PA surface before and after chalcogenation with selenopentathionic and telluropentathionic acids show that a new material was formed or bonded on the surface of PA after chalcogenation (Figure 3). FTIR spectra show the great similarity for both chalcogens layers on PA surface formed using selenium and tellurium containing precursors in the region of frequencies $500-1300 \mathrm{~cm}^{-1}$ (Figures 3(a), 3(b)). The peaks of most intensive bands in the IR spectra of chalcogenized PA recorded by a compensation method (a PA absorption eliminated) were present in the intervals of the wave numbers $427-735 \mathrm{~cm}^{-1}$ and $790-1372 \mathrm{~cm}^{-1}$. Six main absorption bands in the region $350-1200 \mathrm{~cm}^{-1}$ may be assigned to the vibration of $\mathrm{S}_{2} \mathrm{O}_{3}^{2-}$ [15].

A very strong band with the peak was shown in the range $1209-1215 \mathrm{~cm}^{-1}$. The lower frequency absorption with the peak at $609 \mathrm{~cm}^{-1}$ was reasonably strong and the band was sharp and clear cut so that it was coupled with the stretching absorption. A broad absorption in the region $608-610 \mathrm{~cm}^{-1}$ 


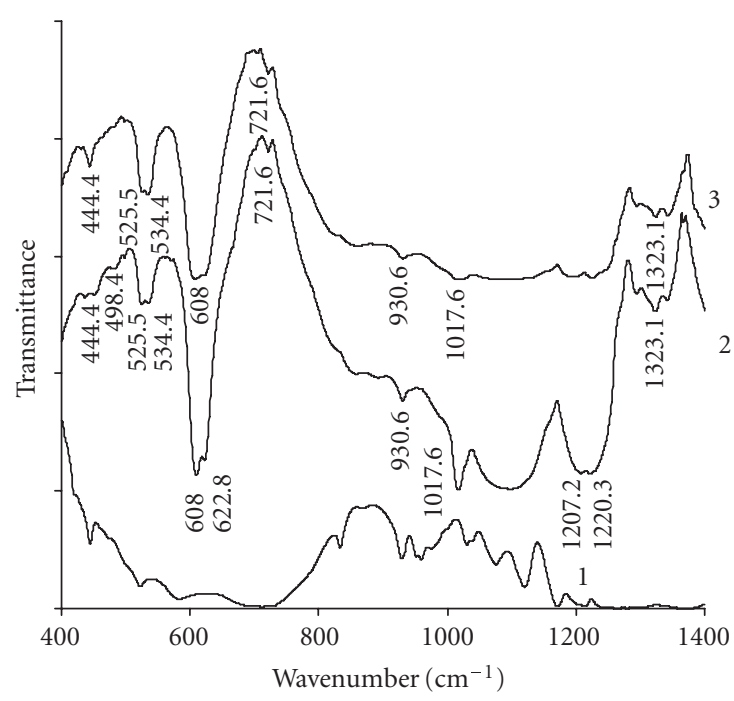

(a)

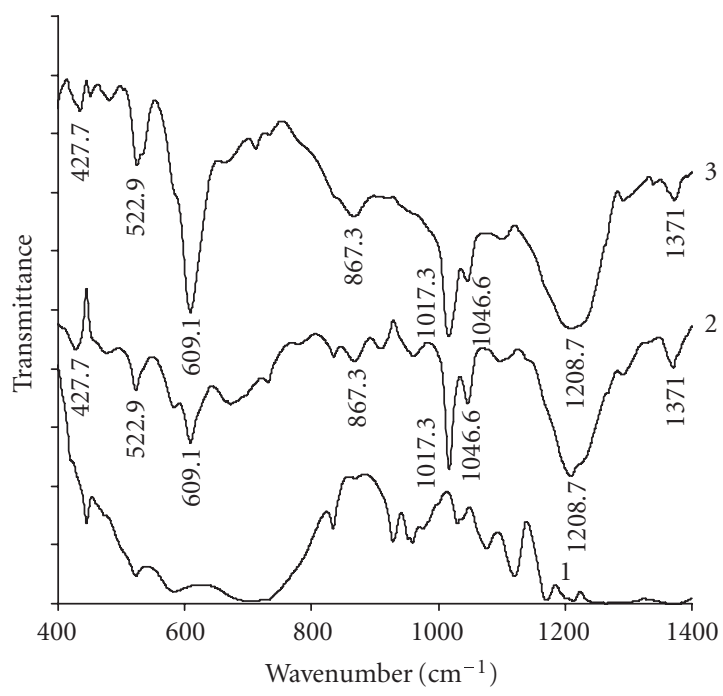

(b)

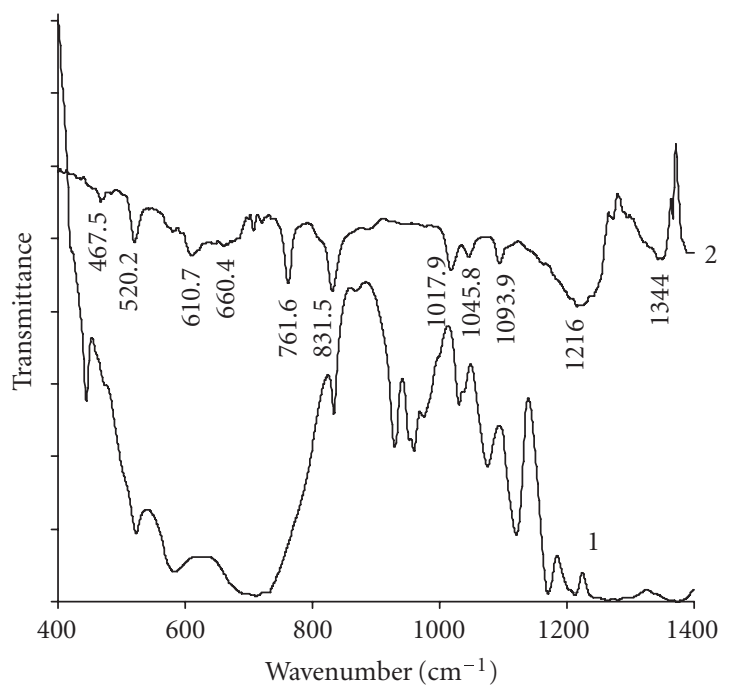

(c)

FIGURE 3: (a) IR absorption spectra of PA (1) and the layers of chalcogens on PA surface after 4 hours (2), and 24 hours (3) exposure in $0.5 \mathrm{~mol} \cdot \mathrm{dm}^{-3}$ solution of $\mathrm{H}_{2} \mathrm{SeS}_{4} \mathrm{O}_{6}$ at $20^{\circ} \mathrm{C}$. (b) IR absorption spectra of PA and the layers of chalcogens on PA surface after $1 \mathrm{hour}(1)$ and after 24 hours (2) exposure in $0.1 \mathrm{~mol} \cdot \mathrm{dm}^{-3}$ solution of $\mathrm{H}_{2} \mathrm{TeS}_{4} \mathrm{O}_{6}$ at $20^{\circ} \mathrm{C}$. (c) IR absorption spectra of PA (1) and the layers of copper chalcogenides on PA surface after 24 hours (2) exposure in $0.1 \mathrm{~mol} \cdot \mathrm{dm}^{-3}$ solution of $\mathrm{H}_{2} \mathrm{TeS}_{4} \mathrm{O}_{6}$ at $20^{\circ} \mathrm{C}$.

is typical to the symmetric deformation $\mathrm{O}-\mathrm{S}-\mathrm{O}$ vibrations, $\delta_{s}(\mathrm{O}-\mathrm{S}-\mathrm{O})$, in the terminal $\mathrm{SO}_{3}$ groups of the polythionates $[16,17]$.

The bands with the peaks in the interval of the wave numbers $790-1302 \mathrm{~cm}^{-1}$ correspond to the symmetric valence $\mathrm{S}-\mathrm{O}$ vibrations, $v_{s}(\mathrm{~S}-\mathrm{O})$, and to the asymmetric valence $\mathrm{S}-\mathrm{O}$ vibrations, $v_{a s}(\mathrm{~S}-\mathrm{O})$, in the terminal $\mathrm{SO}_{3}$ groups of the polythionates [17].

However, the absorption intensity at $523-735 \mathrm{~cm}^{-1}$ considerably increased when the process of chalcogenation proceeded. The bands with the peaks in this interval of the wave numbers correspond to the asymmetric deformation of $\mathrm{O}-\mathrm{S}-\mathrm{O}$ vibrations, $\delta_{a s}(\mathrm{O}-\mathrm{S}-\mathrm{O})$, and to the symmetric deformation $\mathrm{O}-\mathrm{S}-\mathrm{O}$ vibrations, $\delta_{s}(\mathrm{O}-\mathrm{S}-\mathrm{O})$, in the terminal
$\mathrm{SO}_{3}$ groups of the polythionates [16]. Also, the absorption bands in the region $>500 \mathrm{~cm}^{-1}$ of spectra of Te containing layers on PA indicate the shift to the side of lower frequencies compared with that for Se containing layers.

FT-IR spectra suggest the preliminary formation mechanism of thin layers of chalcogens from $\mathrm{SeS}_{4} \mathrm{O}_{6}^{2-}$ or $\mathrm{TeS}_{4} \mathrm{O}_{6}^{2}$ ions containing precursors on PA surface. From a point of view of the mechanism of formation of nanofilms on PA surface, the key problem is that the layers of chalcogens or their compounds, probably chalcogenides, obtained block the surface sites of polymer, modifying their surface properties. It might be postulated that the new groups represent the formation of polychalcogens and polychalcogenides. 
Further interaction of chalcogenized polyamide with copper (II/I) salt solution leads to the formation of $\mathrm{Cu}_{\mathrm{x}} \mathrm{S}$, $\mathrm{Cu}_{\mathrm{x}} \mathrm{Se}, \mathrm{Cu}_{\mathrm{x}} \mathrm{Te}$ and mixed $-\mathrm{Cu}_{\mathrm{x}} \mathrm{S}-\mathrm{Cu}_{\mathrm{y}} \mathrm{Se}$ and $\mathrm{Cu}_{\mathrm{x}} \mathrm{S}-\mathrm{Cu}_{\mathrm{y}} \mathrm{Te}$ layers, which IR spectra are quite different from that of PA before the interaction with copper (Figure 3(c)). The IR absorption spectra after interaction with copper salt are presented for PA, chalcogenized in the telluropentathionic acid, because only the reflection spectra have been recorded for PA surface chalcogenized in the selenopentathionic acid. The phase composition of layers depends on the duration of initial treatment in precursor's solution: $\mathrm{Cu}_{\mathrm{x}} \mathrm{S}_{\mathrm{y}}-\mathrm{Cu}_{\mathrm{x}} \mathrm{Se}_{\mathrm{y}}$ layers are composed of a chalcocite, $\mathrm{Cu}_{2} \mathrm{~S}$, digenite, $\mathrm{Cu}_{1.8} \mathrm{~S}$, djurleite, $\mathrm{Cu}_{1.9375} \mathrm{~S}$, anilite, $\mathrm{Cu}_{1.75} \mathrm{~S}$ and of selenides-bellidoite, $\mathrm{Cu}_{2} \mathrm{Se}$, umangite, $\mathrm{Cu}_{3} \mathrm{Se}_{2}$, klockmannite, $\mathrm{CuSe}$, krutaite, $\mathrm{CuSe}_{2}$ and $\mathrm{Cu}_{2} \mathrm{Se}_{\mathrm{x}}[10] . \mathrm{Cu}-\mathrm{Te}-\mathrm{S}$ layers have binary phases such as $\mathrm{Cu}_{2} \mathrm{Te}, \mathrm{Cu}_{3-\mathrm{x}} \mathrm{Te}_{2}, \mathrm{Cu}_{2-\mathrm{x}} \mathrm{S}$ : copper telluride, $\mathrm{Cu}_{2.72} \mathrm{Te}_{2}$, vulcanite, $\mathrm{CuTe}$, anilite, $\mathrm{Cu}_{7} \mathrm{~S}_{4}$ and digenite, $\mathrm{Cu}_{1.8} \mathrm{~S}$ [11]. As in the case of UV VIS spectra analysis, in order to clarify the structural attribution of the FTIR absorption bands, some experiments have to be carried out.

The transition-metal chalcogenides, because of their rich structural chemistry, have been studied extensively [18]. These compounds exhibit a strong metal chalcogen bonding within a layer or chain and weak van der Waals' interactions between these layers or chains. In the transition-metal chalcogenides the metal-chalcogen bonds are more covalent and chalcogen ions are less highly charged. The decreased electronegativity of the chalcogens from $S$ to Te is often accompanied by the presence of $\mathrm{Q}-\mathrm{Q}$ bonding. Among the transition-metal chalcogenides, the tellurides are further distinguished in their structural and physical properties. These differences can be determined by the large ionic radius and decreased electronegativity.

We have used a variety of techniques (UV-VIS, FT-IR spectrophotometry, X-ray diffraction) to assess and to explain the mechanisms; reactions of the formation and stoichiometry of layers of copper chalcogenides. While we have not as yet been able to elucidate every detail of mechanism for all the stages of the interaction, we believe the following reactions are involved in the formation of copper chalcogenides.

The chalcopolythionates ions $\mathrm{ES}_{4} \mathrm{O}_{6}^{2-}(\mathrm{E}-\mathrm{Se}, \mathrm{Te})$ contain a mixed chain of three divalent chalcogen atoms ${ }^{-} \mathrm{O}_{3} \mathrm{~S}-\mathrm{S}-\mathrm{Se}-\mathrm{S}-\mathrm{S}-\mathrm{O}_{3}{ }^{-}$or ${ }^{-} \mathrm{O}_{3} \mathrm{~S}-\mathrm{STe}-\mathrm{S}-\mathrm{S}-\mathrm{O}_{3}{ }^{-}$as precursors of chalcogens. Selenopentathionate and telluropentathionate are characterized as selenium or tellurium dithiosulfate, namely, $\left[\mathrm{Se}\left(\mathrm{S}_{2} \mathrm{O}_{3}\right)_{2}\right]^{2-}$ or $\left[\mathrm{Te}\left(\mathrm{S}_{2} \mathrm{O}_{3}\right)_{2}\right]^{2-}$, that is, two thiosulfate groups are bonded to a chalcogen atom through the sulfur atoms [16]. The degree of ionic character of the covalent tellurium-sulfur bonds in telluropentathionate ${ }^{-2} \mathrm{O}_{3} \mathrm{~S}_{2} \mathrm{Te}^{++} \mathrm{S}_{2} \mathrm{O}_{3}^{2-}$ should be definitely larger than in the case of corresponding bonds in pentathionate, $\left[\mathrm{S}\left(\mathrm{S}_{2} \mathrm{O}_{3}\right)_{2}\right]^{2-}$, and selenopentathionate, $\left[\mathrm{Se}\left(\mathrm{S}_{2} \mathrm{O}_{3}\right)_{2}\right]^{2-}$, the electronegativity values of sulfur, selenium, and tellurium being $2.5,2.4$, and 2.1, respectively [18].

The liberation of selenium or tellurium from selenopentathionate or telluropentathionate may formally be regarded as a redox process, as an oxidation of the thioanion $\mathrm{SX}^{-}$by $\mathrm{Se}^{++}$or $\mathrm{Te}^{++}$:

$$
\begin{aligned}
& 2 \mathrm{SX}^{-}+\mathrm{Se}^{++}=(\mathrm{SX})_{2}+\mathrm{Se} \\
& 2 \mathrm{SX}^{-}+\mathrm{Te}^{++}=(\mathrm{SX})_{2}+\mathrm{Te}
\end{aligned}
$$

Multifunctional chelating groups of polyamide, namely, carboxylic and amido, have strong interaction (electrostatic force, coordinate bonding, and hydrogen bonding) with chalcopolythionate and metal ions to establish stable polymeric complexes, for example, the electrostatic interaction of charged ions of sorbate, namely, $\mathrm{TeS}_{4} \mathrm{O}_{6}^{2-}, \mathrm{SeS}_{4} \mathrm{O}_{6}^{2-}, \mathrm{H}^{+}$ with charged sites of the sorbent and exchange reactions of these ions with ligands previously bond to the polymer's surface or their ionized functional groups. Selenopentathionic and telluropentathionic acids are only recently isolated as free acids. Despite the fact that these chalcopolythionic acids are strong diprotic acids and are sufficiently stable during the treatment, the $-\mathrm{S}-\mathrm{S}-\mathrm{Se}-\mathrm{S}-\mathrm{S}-$ or $-\mathrm{S}-\mathrm{S}-\mathrm{Te}-\mathrm{S}-\mathrm{S}-$ chain is not kept during the sorption process.

Attachment procedures on internal pore surfaces of functionalized chelating polymers have been extensively studied for metal ions sorption [19]. A special role must be attributed also to an interaction of copper $\left(\mathrm{Cu}^{2+}, \mathrm{Cu}^{+}\right)$ions with the sorbed products of the reduction of $\mathrm{Se}^{2+}, \mathrm{Te}^{2+}$, and $\mathrm{S}^{2+}$ from the chalkopolythionates anions. Sulfur, selenium or tellurium, either as the free chalcogenides ions or when covalently bound in amido group of PA, behave as a very effective Lewis base towards many transition metals, for example, iron, copper, zinc or molybdenum [12].

Some $\mathrm{Cu}-\mathrm{S}, \mathrm{Cu}-\mathrm{Se}$ or $\mathrm{Cu}-\mathrm{Te}$ redox amines contain metal chalcogenides clusters in which chalcogenides ions bridge the copper atoms, the clusters themselves being attached to the amido group by amine chalcogen-copper bonding. Several thiols occur naturally; for example, the thiol group of the natural amino acid cysteine. A covalent bond between two sulfur atoms like disulfide bonds are formed between side chains of two cysteine units by oxidation of their thiol groups $-\mathrm{SH}$ to form a disulfide bond or a disulfide bridge. The sulfur analogs, namely selenium and tellurium, form selenohydryl, $-\mathrm{SeH}$, and tellurohydryl, $-\mathrm{TeH}$, groups. The sulfur-sulfur or chalcogen-chalcogen bond in di- and polysulfides, $\mathrm{di}-$ and polyselenides or in $\mathrm{di}-$ and polytellurides is easily cleaved particularly by nucleophilic reagents.

Chemical reduction of metal ions $\left(\mathrm{Fe}^{2+}, \mathrm{Cu}^{2+}, \mathrm{Pd}^{+}\right.$, etc.) by the reducing agent (hydrazine or hydroquinone) is the most common method for the preparation of metal nanolayers. Nanosized copper chalcogenides $\mathrm{CuSe} / \mathrm{CuS}$ or $\mathrm{CuTe} / \mathrm{CuS}$ layers were immobilized inside the polyamidic matrix by treatment of chalcogenized $\mathrm{PA}$ with copper salt $\mathrm{CuSO}_{4} 5 \mathrm{H}_{2} \mathrm{O}$ after reduction with hydroquinone.

\subsection{X-ray diffraction}

The formed layers of copper chalcogenides were examined applying the X-ray diffraction technique. The XRD patterns 


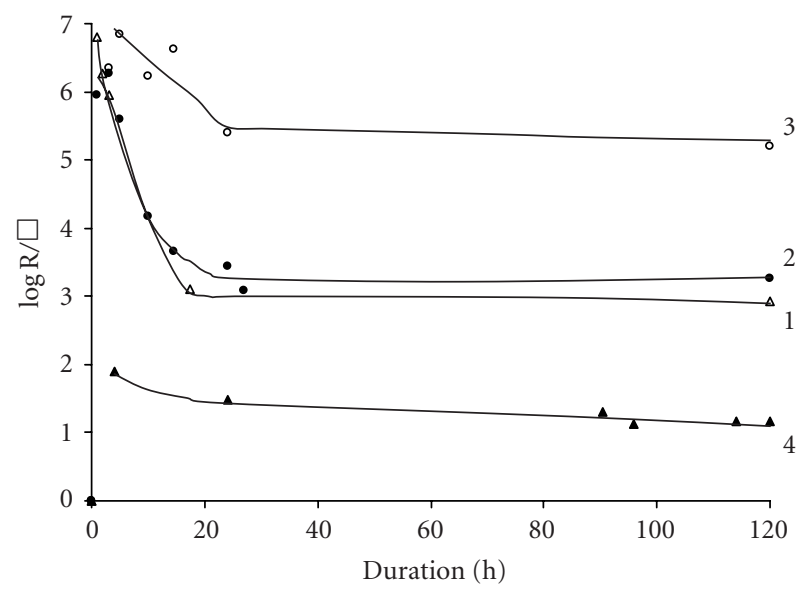

FIGURE 4: Log sheet resistance of chalcogenides layers on PA surface versus exposure time in (1) 0.1 , (2) 0.05 , (3) $0.01 \mathrm{~mol} \cdot \mathrm{dm}^{-3}$ $\mathrm{H}_{2} \mathrm{TeS}_{4} \mathrm{O}_{6}$, and (4) $0.5 \mathrm{~mol} \cdot \mathrm{dm}^{-3} \mathrm{H}_{2} \mathrm{SeS}_{4} \mathrm{O}_{6}$.

(not shown here) of the layers prepared by the above method and published in previous publications $[10,11]$ confirm that the films present very good crystallization. Characteristic reflections of sulfides $\left(\mathrm{Cu}_{\mathrm{x}} \mathrm{S}_{\mathrm{y}}\right)$, selenides $\left(\mathrm{Cu}_{\mathrm{x}} \mathrm{Se}_{\mathrm{y}}\right)$, and tellurides $\left(\mathrm{Cu}_{\mathrm{x}} \mathrm{Te}_{\mathrm{y}}\right)$ phases were detected. The elemental analysis values of the modified polymer by AA and UV-VIS spectroscopy $[11,12]$ were in fair agreement with X-ray structural analysis, which confirmed the formation of mixed copper chalcogenides' layers on PA surface.

\subsection{Electrical resistance}

The electrical resistances of the layers of copper chalcogenides with various composition formed over a vide concentration range $0.01-0.5 \mathrm{~mol} \cdot \mathrm{dm}^{-3}$ of precursors' solution were measured at room temperature. The use of chalcopolytionic acids as new precursors enables the formation on the surface of PA electrically conductive layer of copper sulfidesselenides and copper sulfides-tellurides with electrical resistance in the range of $4.0 \cdot 10^{3} \mathrm{k} \Omega /-14 \Omega /$ (see Figure 4) in dependence on the concentration of initial precursor's solution. An electrical resistance of $\mathrm{Cu}_{\mathrm{x}} \mathrm{S}-\mathrm{Cu}_{\mathrm{y}} \mathrm{Se}$ layers varies from $86 \Omega /$ to $14,3 \Omega / . \mathrm{Cu}_{\mathrm{x}} \mathrm{S}-\mathrm{Cu}_{\mathrm{y}} \mathrm{Te}$ layers have the resistance in the range of $4.0 \cdot 10^{3} \mathrm{k} \Omega /-1.0 \mathrm{k} \Omega /$. This value exhibits a minimum at the exposure time 120 hours for both, copper sulfides-selenides and copper sulfides-tellurides containing layers (Figure 4).

Variation in the conductivity of layers of $\mathrm{Cu}-\mathrm{Se}-\mathrm{S}$ and $\mathrm{Cu}-\mathrm{Te}-\mathrm{S}$ on the surface of PA shows an evident increase with the increasing of the mass fraction of sorbed chalcogen, respectively, selenium or tellurium, for example, with thickness of the layer. (Figures 1 and 4). However, the resistance value of the layers containing copper selenides was about 1000 time less than that of the layers containing copper tellurides. These layers may be considered more conductive. The resistance value can be easily controlled by choosing the concentration of the original precursor's solution and the exposure time. The modification of PA leads to a type conversion ( $p$-type to metallic) during the exposure.

\subsection{Atomic forces microscopy}

As formation of copper chalcogenides layers on PA is mainly surface process, atomic force microscopy proves to be a valuable tool for obtaining quantitative surface data. Figure 5 illustrates the $10 \mu \mathrm{m} \times 10 \mu \mathrm{m}$ top view image of the chalcogenides layers together with its roughness representation. This section analysis was performed from the lower left to the upper right position of the top view image. It is evident that the layers consist of interconnected grain particles fused together, possessing an average grain diameter of about $25 \mathrm{~nm}$. This value is in agreement with X-ray diffraction results [11].

Their height histogram shows a Gaussian-like distribution with a max at $160 \mathrm{~nm}$. The rms value ( $\mathrm{rms}$ is defined as the standard deviation of the $Z$-values, $Z$ being the total height range analyzed) of $206.6 \mathrm{~nm}$ depicts that the copper chalcogenides layers on the surface of PA present high surface characteristics.

\section{CONCLUSIONS}

(1) The layers of chalcogens-sulfur, selenium, and tellurium were formed on the surface of polyamide 6 using new precursors: monoselenopentathionic and monotelluropentathionic acids. Further step-treatment of chalcogenized polyamide with copper (II/I) salt solution leads to the formation of $\mathrm{Cu}_{\mathrm{x}} \mathrm{S}, \mathrm{Cu}_{\mathrm{x}} \mathrm{Se}, \mathrm{Cu}_{\mathrm{x}} \mathrm{Te}$, and mixed $-\mathrm{Cu}_{\mathrm{x}} \mathrm{S}-\mathrm{Cu}_{\mathrm{y}} \mathrm{Se}$ and $\mathrm{Cu}_{\mathrm{x}} \mathrm{S}-\mathrm{Cu}_{\mathrm{y}} \mathrm{Te}$ layers on the surface of polyamide.

(2) The intensity of sorption and amount of sorbed selenium and tellurium increase with the increase of the concentration of precursor's solution and an exposure time.

(3) Optical adsorption spectra of chalcogens thin films on PA revealed that films have high absorbance $\left(10^{4} \mathrm{~cm}^{-1}\right)$ indicating direct band gap transition.

(4) IR spectra of modified PA show that a new material chemically bonded with PA functional groups after chalcogenation.

(5) The use of chalcopolytionic acids as new precursors enables the formation on the surface of polyamide electrically conductive layer of copper sulfides-selenides and copper sulfides-tellurides with electrical resistance in the range of $4.0 \cdot 10^{3} \mathrm{k} \Omega /-14 \Omega /$. An electrical resistance of $\mathrm{Cu}_{\mathrm{x}} \mathrm{S}-\mathrm{Cu}_{\mathrm{y}} \mathrm{Se}$ layers varies from $86 \Omega /-14,3 \Omega / . \mathrm{Cu}_{\mathrm{x}} \mathrm{S}-\mathrm{Cu}_{\mathrm{y}} \mathrm{Te}$ layers have the resistance in the range of $4.0 \cdot 10^{3} \mathrm{k} \Omega /-1.0 \mathrm{k} \Omega /$. The modification of PA leads to a type conversion ( $p$-type to metallic) during the exposure.

(6) The surface properties of PA after treatment are studied using AFM. Atomic force microscopy images prove that the copper chalcogenides layers on the surface of PA present high surface characteristics.

\section{ACKNOWLEDGMENT}

The support of the Research Centre for Microsystems and Nanotechnology (Kaunas University of Technology) is gratefully acknowledged. 

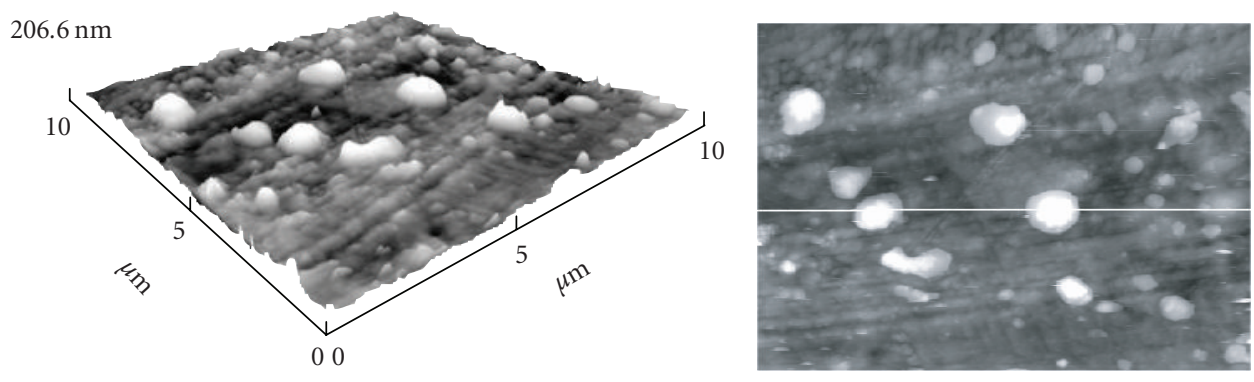

(a)

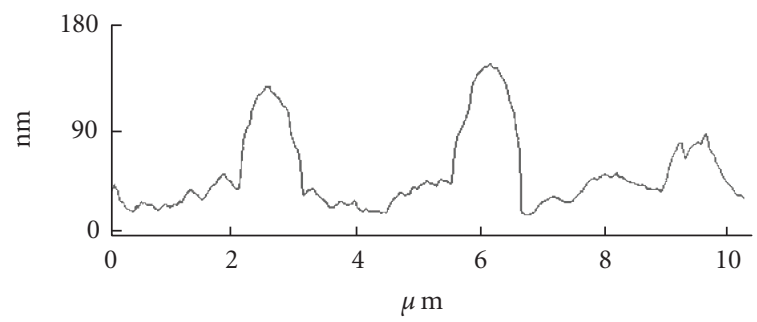

(b)

FIgURE 5: (a) AFM top view of the layers of copper chalcogenides and (b) corresponding section.

\section{REFERENCES}

[1] Ch. Ma, D. Moore, Y. Ding, J. Li, and Z. L. Wang, "Nanobelt and nanosaw structures of II-VI semiconductors," International Journal of Nanotechnology, vol. 1, no. 4, pp. 431-451, 2004.

[2] W. S. Chen, J. M. Stewart, and R. A. Mickelsen, "Polycrystalline thin-film $\mathrm{Cu}_{2-x} \mathrm{Se} / \mathrm{CdS}$ solar cell," Applied Physics Letters, vol. 46, no. 11, pp. 1095-1097, 1985.

[3] C. Naşcu, I. Pop, V. Ionescu, E. Indrea, and I. Bratu, "Spray pyrolysis deposition of CuS thin films," Materials Letters, vol. 32, no. 2-3, pp. 73-77, 1997.

[4] H. Okimura, T. Matsumae, and R. Makabe, "Electrical properties of $\mathrm{Cu}_{2-x}$ Se thin films and their application for solar cells," Thin Solid Films, vol. 71, no. 1, pp. 53-59, 1980.

[5] M. A. Korzhuev, "Dufour effect in superionic copper selenide," Physics of the Solid State, vol. 40, no. 2, pp. 217-219, 1998.

[6] M. Emziane, K. Durose, N. Romeo, A. Bosio, and D. P. Halliday, "Effect of $\mathrm{CdCl}_{2}$ activation on the impurity distribution in CdTe/CdS solar cell structures," Thin Solid Films, vol. 480481, pp. 377-381, 2005.

[7] O. Foss, "Salts of monotelluropentathionic acid," Acta Chemica Scandinavica, vol. 3, pp. 708-716, 1949, ibid. "The interrelationship between monoseleno polythionates," pp.435-444.

[8] V. I. Zelionkaite and V. J. Šukyte, "About the solutions of selenopentathionic acid," Journal of Inorganic Chemistry, vol. 18, no. 9, p. 2347, 1973 (Russian).

[9] J. Sukyte, R. Ivanauskas, and V. Janickis, "Chemistry and technology of inorganic compounds," in Proceedings of the Conference of "Lithuanian Science and Industry", p. 53, Kaunas, Lithuania, April 2004.

[10] R. Ivanauskas, V. Janickis, and N. Petrašauskienė, "Modification of polyamide (PA) films by layers of copper sulfidesselenides," Materials Science, vol. 6, no. 4, pp. 298-301, 2000.
[11] R. Ivanauskas, J. Sukyte, V. Janickis, and N. Petrašauskienè, "Modification of polyamide (PA) films by layers of mixed copper sulfidescopper tellurides," Materials Science, vol. 10, no. 1, pp. 29-33, 2004.

[12] V. J. Šukyte, R. Ivanauskas, and V. Janickis, "Preparation and some properties of $\mathrm{Cu}-\mathrm{Te}-\mathrm{S}$ thin films on the polyamide (PA) surface," Polish Journal of Chemistry, vol. 79, no. 4, pp. 759771, 2005.

[13] K. Nakamoto, Infrared and Raman Spectra of Inorganic and Coordination Compounds, John Wiley \& Sons, New York, NY, USA, 1986.

[14] I. Bružaite, V. Janickis, I. Ancutiene, and V. Snitka, "Formation of thallium sulphide layers on polyethylene (PE) sulphurised in a solution of higher polythionic acid," Diffusion and Defect Data Pt.B: Solid State Phenomena, vol. 106, pp. 133-138, 2005.

[15] E. R. Clark and A. J. Collett, "Infrared and Raman spectra of seleno- and telluro-pentathionates," Journal of the Chemical Society A: Inorganic, Physical, Theoretical, no. 10, pp. 15941596, 1969.

[16] O. Foss, "Structures of compounds containing chains of sulfur atoms," in Advances in Inorganic Chemistry and Radiochemistry, H. J. Emeleus and A. G. Sharpe, Eds., vol. 2, p. 237, Academic Press, New York, NY, USA, 1960.

[17] V. Janickis and J. Janickis, "IR absorption spectra of potassium selenopolythionates," Transactions of Lithuanian Academy of Sciences. Series B, vol. 6, p. 43, 1986.

[18] P. M. Keane and H. F. Hanzen, "Chalcogenides: solid state chemistry," in Encyclopedia of Inorganic Chemistry, R. B. King, Ed., p. 610, John Wiley \& Sons, New York, NY, USA, 1994.

[19] J. A. Hestekin, L. G. Bachas, and D. Bhattacharyya, "Poly(amino acid)-functionalized cellulosic membranes: metal sorption mechanisms and results," Industrial and Engineering Chemistry Research, vol. 40, no. 12, pp. 2668-2678, 2001. 


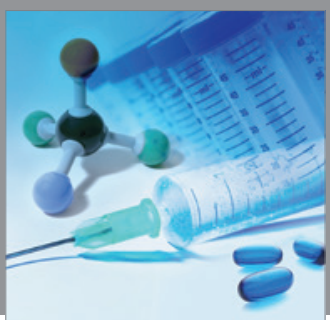

International Journal of

Medicinal Chemistry

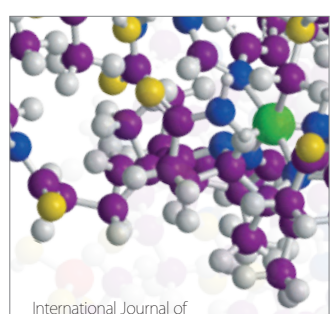

Carbohydrate Chemistry

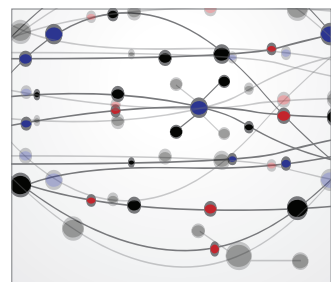

The Scientific World Journal
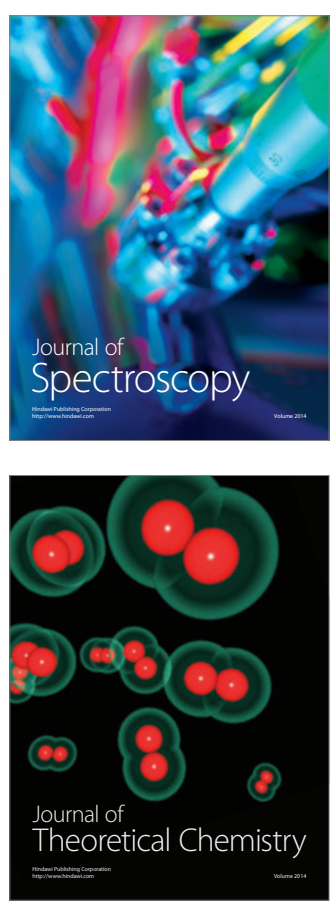
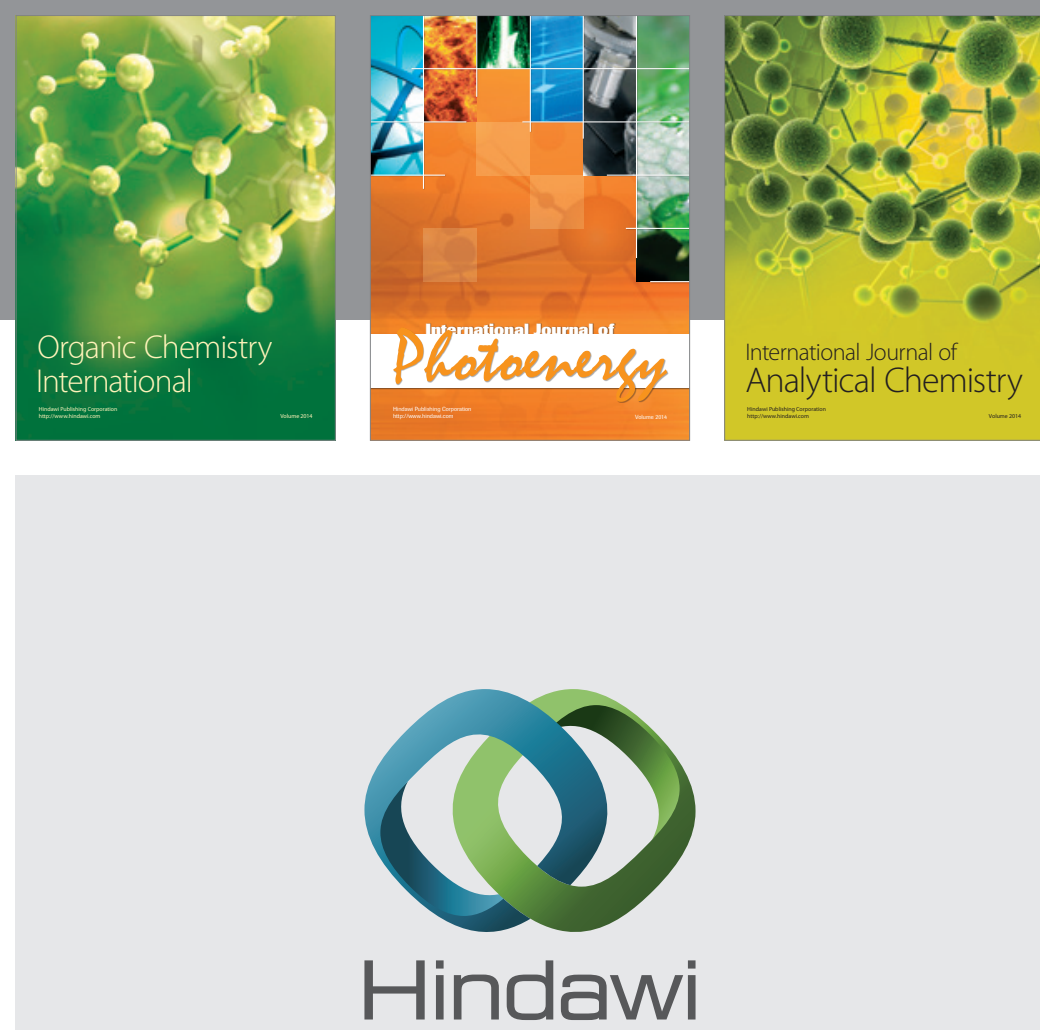

Submit your manuscripts at

http://www.hindawi.com
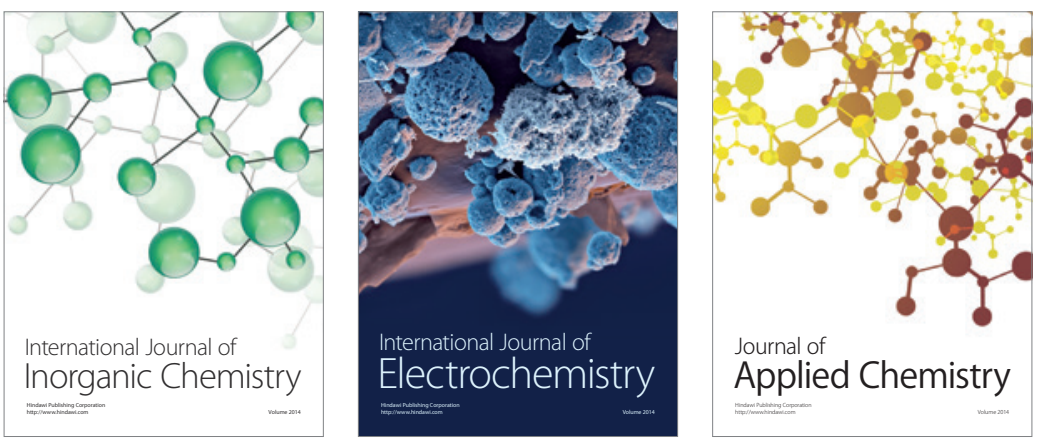

Journal of

Applied Chemistry
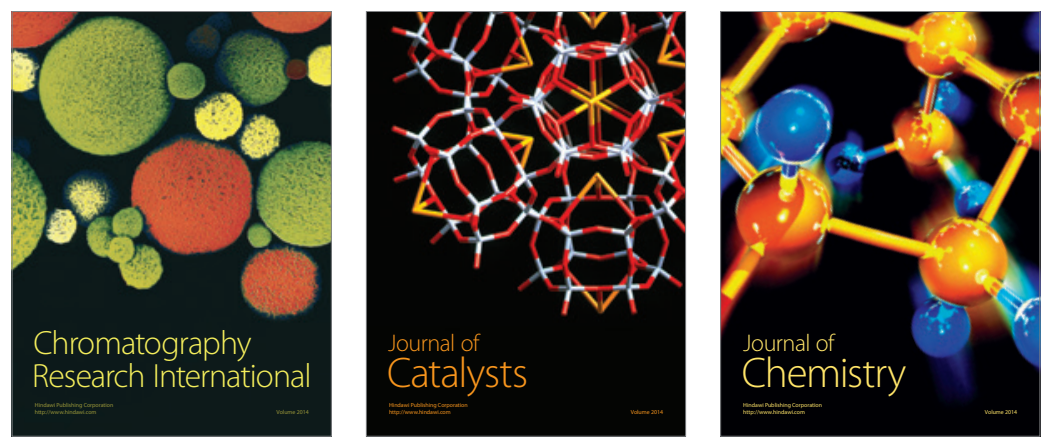
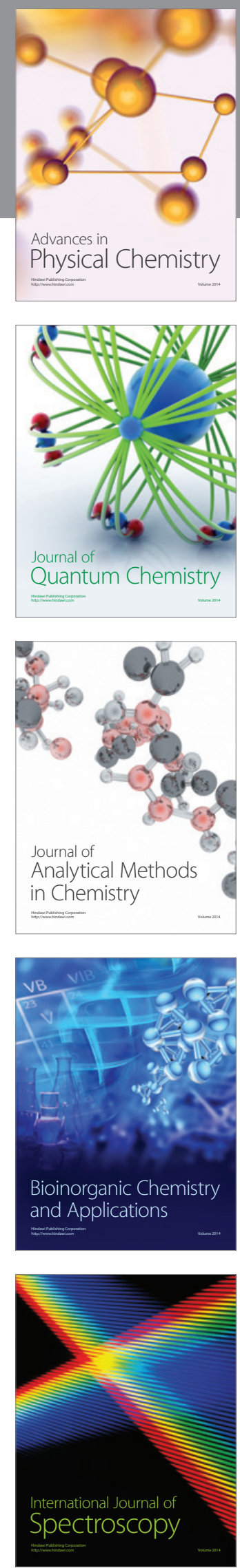